\title{
TOXICITY EVALUATION OF AMMONIUM SULFATE TO ALBINO RAT
}

\author{
SIVA KUMAR T, SHOBHA RANI A, SUJATHA K, PURUSHOTHAM B, NEERAJA P*
}

Department of Zoology, Division of Toxicology, Sri Venkateswara University, Tirupati, Andhra Pradesh, India. Email: pneeraja@svuniversity.ac.in

Received: 24 September 2016, Revised and Accepted: 15 October 2016

\section{ABSTRACT}

Objective: The present study was designed to find out the acute median lethal dose $\left(\mathrm{LD}_{50}\right)$ of ammonium sulfate (inorganic fertilizer) in Wister albino rats.

Methods: A single dose of ammonium sulfate dissolved in distilled water (Milli-Q) and administered intraperitoneally at concentrations of $10,30,50$, $70,90,110,130$, and $170 \mathrm{mg} / \mathrm{kg}$ body weight, respectively, to experimental animals, and then, they were observed every 3 hrs from prior dose given time, later $6 \mathrm{hrs}, 12 \mathrm{hrs}, 24 \mathrm{hrs}$, to $48 \mathrm{hrs}$ of noticing any abnormal behaviors and toxic signs, symptoms. After 48 hrs, counted the number of rats departed in each group and mortality percentage was calculated.

Results: The obtained results were evaluated by the Statistical Probit Analysis Method and 48 hrs $\mathrm{LD}_{50}$ value for albino rats was found to be $91.5 \mathrm{mg} / \mathrm{kg}$. At a single dose of $10 \mathrm{mg} / \mathrm{kg}$, there is no morality and toxic behaviors were observed. Therefore, this concentration is considered as no observed adverse effect level dose.

Conclusion: From the earlier consequences, identification and evaluation of the $\mathrm{LD}_{50}$ against ammonium sulfate is crucial for understanding the hyperammonemia because ammonium sulfate has been highly utilized as inorganic fertilizer in agriculture and household gardens. Thus, the knowledge about toxic impacts of ammonia useful for clinical or toxicological approaches; however, the toxicity data are unclear. Hence, the in vitro $\mathrm{LD}_{50}$ evaluations of target chemical in Wistar rats is highly associated toward in ammonia-related peculiar disorders perceptive and therapy.

Keywords: Ammonium sulfate, Fertilizer, Median lethal dose, Mortality, No observed adverse effect level.

(C) 2017 The Authors. Published by Innovare Academic Sciences Pvt Ltd. This is an open access article under the CC BY license (http://creativecommons. org/licenses/by/4. 0/) DOI: http://dx.doi.org/10.22159/ajpcr.2017.v10i1.15355

\section{INTRODUCTION}

Ammonium $\left(\mathrm{NH}_{4}^{+}\right)$, nitrite $\left(\mathrm{NO}_{2}^{-}\right)$, and nitrate $\left(\mathrm{NO}_{3}^{-}\right)$are main inorganic substrates of nitrogen. Ammonia is an essential nitrogen substrate in aquatic and terrestrial living organisms including plants. It plays a potential role in maintaining the nitrogen homeostasis in the body and also the precursor for amino acids and protein metabolism. Most of the nitrogen substrates are utilized in the fertilizer industries; they produce different ammonium-related compounds such as ammonium sulfate, ammonium nitrate, ammonium acetate, and ammonium chloride. Among them, ammonium sulfate is used as popularized agricultural fertilizer and used in house gardens [1]. Ammonium sulfate is moreover used in the field of food and beverage industries and printing of the papers. Whatever may be limited utilization safe and secured, in case of in excess of utilization leads to environmental pollution and shows the effect on physiological functions of living organisms. Environmental pollution pollutes the air, water, soil, and consequently in food which may be poisonous or toxic and will cause harm to living things [2]. The excessive amount of pollutants in animal feed and feedstuffs are often due to human actions, resulting from either agricultural or industrial production or accidental or deliberate misuse. Automobile industries liberate the ammonium-related compounds, by an increase in the number of diesel engines emitting exhaust, due to factors such as fuel efficiency and the economical nature of these engines, especially in industrialized and developing countries [3]. Ammonium sulfate and ammonium nitrate are major air pollutants found in diesel exhaust and as inorganic particulates in the atmosphere. These compounds have been shown to be harmful to human health in epidemiological studies [4]. Of this fertilizer, few case reports on toxicological studies of ingested fertilizers have been reported.

Toxicity testing is used a wide range of tests in different species of animals with the short-term and long-term administration of the drug, usual monitoring of physiological, biochemical deforms, and comprehensive post-mortem examination at the end of the trial to detect gross or histological abnormalities [5]. The toxicity evaluation of chemicals is identified in different ways. However, toxicity related to human estimations is depended on the test results of rats and other animal models through in vitro assessments. In general, chemical toxicity illustrated as median lethal dose $\left(\mathrm{LD}_{50}\right)$, here, $\mathrm{LD}$ means a lethal dose deadly amount and the 50 means that the dose is acutely lethal to $50 \%$ of the animals to whom the chemical administered by any of the methods such as oral, dermal, inhalation, intravenous, and intraperitoneal under controlled laboratory conditions. Determination of this test examines the relationship between dose and the most extreme response-death that means the $\mathrm{LD}_{50}$ of any chemical is directly proportional to dose response-death. The $\mathrm{LD}_{50}$ is expressed as milligrams of substance per kilogram of animal body weight (mg/kg b.w). It provides information on health hazards likely to arise from short-term and long-term exposure [6,7].

Ammonia is one of the nitrogen pollutant toxicants of the aquatic and terrestrial living organism. Nitrogenous pollutants actually found in freshwater ecosystems due to excess of fertilizers and chemical runoff from land and industrial sewage, these nitrogenous compounds can result to a toxic effect on aquatic living organisms as well as terrestrial living things through the food chain, and then accumulated in the body. Ammonia is a neurotoxin when it accumulates in excess. Excess of ammonium ions levels in the body leads to raised ammonium levels in blood and is responsible for the hyperammonemic condition, by the mode of action of ammonia as a toxin is primarily through its effects on the central nervous system (CNS). Hyperammonemia is mainly responsible for the neurological alterations, impaired intellectual function and consequently leads to hepatic encephalopathy seen in patients with liver disease. Antiepileptic drugs such as valproate and salicylate are also responsible for hyperammonemia and urea 
cycle (UC) disorders [8]. Ammonia has also been a major pathogenic factor associated with inborn errors of UC, Reye's syndrome, organic acidurias, and disorders of fatty acid oxidation [9]. Ammonia toxicity results in generation of free radicals lead to oxidative stress mediated damage of organs [10-12]. However, the acute toxicological reports are fewer; hence, this study has been undertaken to determine the $\mathrm{LD}_{50}$ of ammonium sulfate via intraperitoneal route and acute systemic changes associated with lethal and sublethal doses of ammonium sulfate in rats. Therefore, the predicted $L_{50}$ data are potential for clinical and preclinical aspects toward understanding the toxicity of ammonia for toxicologists/toxicologist, and finally we confined that these assessments are not published in any previous articles. This type of ammonia-related toxicity evaluation studies are ongoing in our lab.

\section{METHODS}

\section{Procurement of chemicals}

The ammonium sulfate chemical was purchased from Molychem Laboratory, Mumbai, India, by local drug store Tirupati, A.P, India.

\section{Animals and experimental design}

Healthy Wister strain albino rats of the same age group ( $100 \pm 10$ days) and weight $200 \pm 10 \mathrm{~g}$ were selected as experimental animals for the present study. The rats were procured from Indian Institute of Science, Bengaluru, India, before experimentation; the animals were acclimatized to laboratory condition. Rats were housed in polypropylene cages lined with clean paddy husk, and provided filtered tap water and rat chow (obtained from the SAI Durga agencies Animal Feed, Bengaluru, India) ad libitum in laboratory conditioned environment $\left(34 \pm 2^{\circ} \mathrm{C}\right)$ with a 12-hrs light and 12-hrs dark cycle. To ascertain $\mathrm{LD}_{50^{\prime}}$ six groups of albino rats, each group comprising of 10 animals. Before dose administration, animals were fasted for $6 \mathrm{hrs}$.

\section{Dosage preparation and administration}

Ammonium sulfate dissolved in distilled water (Milli-Q) and different concentration of ammonium sulfate was administered once intraperitoneally to the rats, using $1 \mathrm{ml}$ syringe. The volume of the dose depends on the size and weight of the animals.

\section{RESULTS}

\section{Behavior signs during experiment}

The behavior of any animal is controlled by neuromuscular coordination and metabolic balance, which is an energy-dependent phenomenon. Initially, administration of ammonium sulfate did not have any effect on behavior signs and mortality, hence that dose $(10 \mathrm{mg} / \mathrm{kg}$ b.w. $)$ considered as no observed adverse effect level (NOAEL) dose. However, when the doses of $50 \mathrm{mg} / \mathrm{kg}$ b.w., $70 \mathrm{mg} / \mathrm{kg}$ b.w., 110, 130, 150, and $170 \mathrm{mg} / \mathrm{kg}$ b.w. were administered, dose effect on the CNS of animals, representing toxic signs such as staggering, prostration, opathy, and labored and irregular breathing were observed. The animals also exhibited abnormal behaviors such as jumping and leaping movements in the cage, scratching the place where the chemical was injected. Abdomen frequently became inflated and the animals were not capable of showing normal movement. Finally, choreoathetosis developed exhibiting slow, writhing, and caricature movements of the neck and tail of animals, then finally to gasping and death. Toxic signs and behavioral abnormalities were noted at doses near to or exceeding the $\mathrm{LD}_{50}$ value. Mortality was noted and graphs were plotted between logconcentration versus percent mortality and log-concentration versus probit mortality and the $\mathrm{LD}_{50}$ is determined.

\section{TOXICITY EVALUATION}

The outcomes of results were computed according to a probit analysis [13] and $\mathrm{LD}_{50}$ values were determined. The animals exposed to different concentrations of ammonium sulfate was shown in Table 1; no mortality was found at $10 \mathrm{mg} / \mathrm{kg}$ b.w., $20 \%$ mortality at $30 \mathrm{mg} / \mathrm{kg}$ b.w., $30 \%$ mortality at $50 \mathrm{mg} / \mathrm{kg}$ b.w., $40 \%$ mortality at $70 \mathrm{mg} / \mathrm{kg}$ b.w., then $60 \%, 70 \%, 80 \%$, and $90 \%$ mortality observed at concentrations of 110 , 130,150 , and $170 \mathrm{mg} / \mathrm{kg}$ b.w., respectively. The mortality rate increased with an increase in the dose concentration of ammonium sulfate. It was also evident that $50 \%$ mortality falls between the concentration of 90 and $110 \mathrm{mg} / \mathrm{kg}$ b.w. The obtained data from dose to percent mortality were processed to derive $50 \%$ mortality and graph gave curvilinear sigmoid or S-shaped curve and $\mathrm{LD}_{50}$ was found to be $91.5 \mathrm{mg} / \mathrm{kg}$ b.w. and was represented in Fig. 1a. When the percent mortality values were converted into probit units and plotted against log concentration (Fig. 1b), the relationship was found to be linear obeying the principles of dose-response studies.

\section{DISCUSSION}

Fertilizers play a prominent role in civilized agriculture by providing depending, required neutrinos to crops. They have, no doubt increased crop yields using required quantities based on the land. In India, most of the agriculture depends on the inorganic, organic fertilizers. Ammonia, urea, and potassium are popular inorganic fertilizers, used as in the combination of NPK; these are common fertilizers for any crop. Ammonium sulfate, ammonium nitrate, ammonium chloride, etc., are well-known ammonium fertilizers, apart from ammonium sulfate familiar nitrate manure used for crops yielding and garden maintaining in the household. At the same time, overutilization of any inorganic substances is becoming as potent pollutants of the environment causing environmental pollution with undesirable effects on living organisms. That's why, the knowledge of $\mathrm{LD}_{50}$ is very important to know about any chemical before use in the field. Therefore, the present study was undertaken to determine the $\mathrm{LD}_{50}$ of ammonium sulfate in rats through intraperitoneal administration. NOAEL is $10 \mathrm{mg} / \mathrm{kg}$ b.w. does not show any visible gross changes and abnormal behavior hence named it as NOAEL. However, animals treated with different concentrations from 70 to $170 \mathrm{mg} / \mathrm{kg}$ b.w. doses showed a sequence of toxic signs and behavioral abnormalities, but the earliest doses of 30 and $50 \mathrm{mg} / \mathrm{kg}$ b.w. showed mild toxic signs.

The graphical illustration of percent mortality versus log concentration and probit mortality versus log concentration (Table 1) showed a distinctive sigmoid curve (Fig. 1a) and a straight line (Fig. 1b) correspondingly which are in superior concurrence with the principle of probit analysis [13]. Toxicity evaluation was not properly explained in any publications. So, the present obtained data from dose to

Table 1: Mortality of Albino rat at different concentrations of ammonium sulfate after $48 \mathrm{hrs}$ of exposure (mortality expressed in both percent and probit kill number of animals exposed to each time is 10)

\begin{tabular}{llllll}
\hline S. No. & Dose $\mathbf{~ m g / k g ~ b o d y ~ w e i g h t ~}$ & Log concentration & Number of rats dead & Percent mortality & Probit mortality \\
\hline 1. & $10 \mathrm{mg}$ & 1.004 & 0 & 0 & 0 \\
2. & $30 \mathrm{mg}$ & 1.477 & 2 & 20 & 4.16 \\
3. & $50 \mathrm{mg}$ & 1.699 & 3 & 30 & 4.48 \\
4. & $70 \mathrm{mg}$ & 1.845 & 4 & 40 & 4.75 \\
5. & $90 \mathrm{mg}$ & 1.954 & 5 & 60 & 5.00 \\
6. & $110 \mathrm{mg}$ & 2.104 & 7 & 70 & 5.25 \\
7. & $130 \mathrm{mg}$ & 2.193 & 8 & 80 & 5.46 \\
8. & $150 \mathrm{mg}$ & 2.294 & 9 & 90 & 6.28 \\
9. & $170 \mathrm{mg}$ & 2.591 & & \\
\hline
\end{tabular}




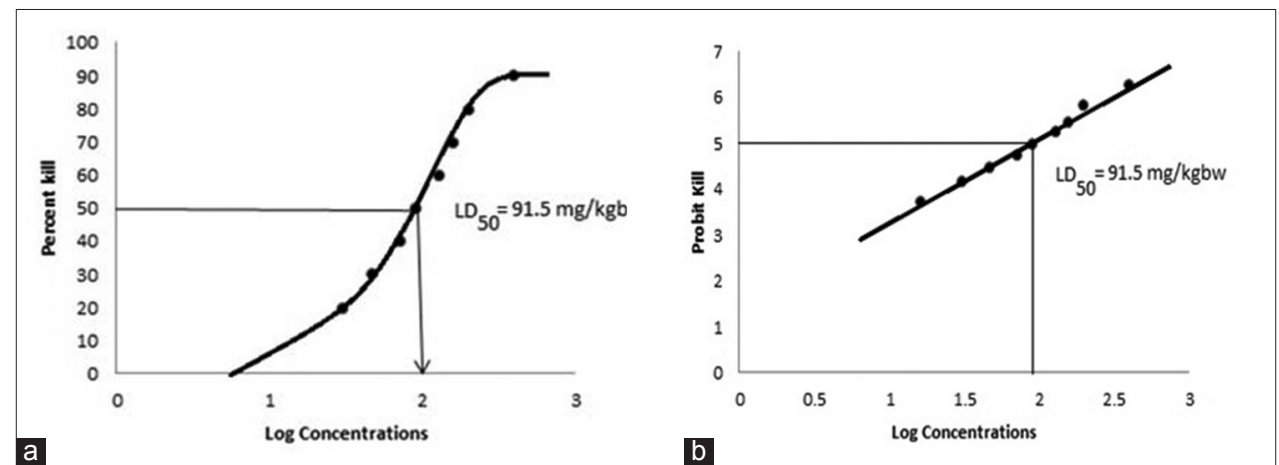

Fig. 1: (a) Sigmoid "Graded Response" curve showing the relation between the log concentrations of ammonium sulfate and percent mortality of the albino rat. (b) Graph showing straight line relation between the log concentration of ammonium sulfate and probit mortality of the albino rat

percent mortality were processed to derive $50 \%$ mortality and graph gave curvilinear sigmoid or S-shaped curve, and $\mathrm{LD}_{50}$ was found to be $91.5 \mathrm{mg} / \mathrm{kg}$ b.w, this would be represented in Fig. 1a. This value was in agreement with $\mathrm{LD}_{50}$ value reported previously by Rani and Neeraja [14]. $\mathrm{LD}_{50}$ value in rats was found to be $90-100 \mathrm{mg} / \mathrm{kg}$ b.w.

Toxicity evaluation of ammonium sulfate in aquatic field well established because of ammonia has a major toxic effect on aquatic living things as unionized ammonia form. Several previous reports are related to ammonium-related components on different fishes, according to that ammonium sulfate showed $50 \%$ mortality rate $\left(\mathrm{LC}_{50}\right)$ in fingerlings of Catla catla during $24 \mathrm{hrs}, 48 \mathrm{hrs}, 72 \mathrm{hrs}$, and 96 hrs with $0.23,0.17,0.14$, and $0.12 \mathrm{~g} / \mathrm{L}$, respectively. In the rainbow trout, ammonium sulfate $\mathrm{LC}_{50}$ with an exposure period of $24 \mathrm{hrs}, 48 \mathrm{hrs}, 72 \mathrm{hrs}$, and $96 \mathrm{hrs}$ that's were $0.242,0198,0.165$, and $0.149 \mathrm{~g} / \mathrm{L}$ reported $[15,16]$. However, the $\mathrm{LC}_{50}$ of ammonium chloride with $48 \mathrm{hrs}$ exposure in Oreochromis niloticus L. (Nile tilapia) larva and fingerlings were determined as $1.007-1.01 \mathrm{mg} / \mathrm{L}$ and 7.39 $7.41 \mathrm{mg} / \mathrm{L}$ in two different replicates, respectively [17]. Similar Daud et al. reported that $6.6 \mathrm{mg} / \mathrm{L}$ for $48 \mathrm{hrs} \mathrm{LC}_{50}$ in hybrid tilapia species [18]. Ambient ammonium $\mathrm{LC}_{50}$ in four different fishes such as Catla, bata, common crop, and tilapia, in the $48 \mathrm{hrs}$ exposure found the different values they are $15,10,25$, and $30 \mathrm{mg} / \mathrm{L}$, respectively [19], and $18.8 \mathrm{mg} / \mathrm{L}$ of ambient ammonia $\mathrm{LC}_{50}$ in Cyprinus carpio was reported in my laboratory for $48 \mathrm{hrs}$ exposure period [20]. Unionized ammonia $\left(\mathrm{NH}_{4} \mathrm{Cl}\right) 24 \mathrm{hrs} \mathrm{LC}_{50}$ and $\mathrm{LC}_{100}$ in Ctenopharyngodon idella fingerlings was $0.05 \mathrm{mg} / \mathrm{L} \mathrm{NH}_{3}-\mathrm{N}$ and $0.075 \mathrm{mg} / \mathrm{L} \mathrm{NH}_{3}-\mathrm{N}$ [21]. Overall consequences are revealed that the different median lethal values occur during ammonia toxicity. Thus, the toxicity effects purely depend on the size and weight of the organisms.

\section{CONCLUSION}

A variety of chemicals show different levels of toxicity potentiality in different animal models indicate that no single chemical showed the same toxicity potentiality. In the present investigation, obtained ammonium sulfate $\mathrm{LD}_{50}$ was $91.5 \mathrm{mg} / \mathrm{kg}$ b.w. in male rat with $48 \mathrm{hrs}$ exposure periods through intraperitoneal method. However, published experimental work on ammonium sulfate toxicity in rat is limited, and there is no experimental work reported on toxicity evaluation of ammonium sulfate by intraperitoneal way. Thus, the present study with ammonium sulfate in rat, which is very useful to have a better understanding in the evaluation of the toxic character and measure the short time potentiality of ammonium sulfate.

\section{ACKNOWLEDGMENT}

T. Siva Kumar greatly acknowledges University Grants Commission (UGC), New Delhi, for awarding BSR-RFSMS research fellowship to carry out this work.

\section{REFERENCES}

1. Sato A, Gonmori K, Yoshioka N. A case of fatal intoxication with ammonium sulfate and a toxicological study using rabbits. Forensic Sci Int 1999;101(2):141-9.

2. Duruibe JO, Ogwuegbu MO, Egwurugwu JN. Heavy metal pollution and human biotoxic effects. Int J Phys Sci 2007;2(5):112-8.

3. Lloyd AC, Cackette TA. Diesel engines: Environmental impact and control. J Air Waste Manag Assoc 2001;51(6):809-47.

4. Valavanidis A, Fiotakis K, Vlachogianni T. Airborne particulate matter and human health: Toxicological assessment and importance of size and composition of particles for oxidative damage and carcinogenic mechanisms. J Environ Sci Health C Environ Carcinog Ecotoxicol Rev 2008;26(4):339-62.

5. Klaassen CS. Principle of toxicology and treatment of poisoning. In: Parker BK, Blumenthal D, Buxton L, editor. Goodman \& Gilman's; Manual of Pharmacology \& Therapeutics. New York: McGraw Hill; 2008. p. 1115-9.

6. Raj J, Chandra M, Dogra TD, Pahuja M, Raina A. Determination of median lethal dose of combination of endosulfan and cypermethrin in wistar rat. Toxicol Int 2013;20(1):1-5.

7. Chandra M, Raj J, Dogra TD, Rajvanshi AC, Raina A. Determination of median lethal dose of triazophos with DMSO in wistar rats. Asian J Pharm Clin Res 2014;7(4), 64-7.

8. Subash S, Subramanian P. Chronotherapeutic effect of Morin in experimental chronic hyperammonemic rats. Int J Nutr Pharmacol Neurol Dis 2012;2:266-71.

9. Subash S, Subramanian P. Impact of morin (a bioflavonoid) on ammonium chloride-mediated oxidative damage in rat kidney. Int $\mathrm{J}$ Nutr Pharmacol Neurol Dis 2011;1:174-8.

10. Vijayakumar N, Subramanian P. Neuroprotective effect of Semecarpus anacardium against hyperammonemia in rats. J Pharm Res 2010;3:1564-8.

11. Kumar TS, Neeraja P. Ameliorative effect of zinc on ammonia induced alterations in antioxidant enzyme levels in kidney tissue of albino rat. AJPT 2015;3(10):31-5.

12. Kumar TS, Neeraja P. Protective effect of Zinc against the Ammonia induced oxidative stress in the rat testes. Int $\mathrm{J}$ Pharm Bio Sci 2015;6(3B):544-8

13. Finney DJ. Probit Analysis. $3^{\text {rd }}$ ed. London: Cambridge University Press; 1971

14. Rani AS, Neeraja P. Ammonia stress induced biochemical changes in liver and brain of Albino rat. Int J Pharm Bio Sci 2013;4(2B):73-8.

15. Sangeetha S, Sujatha K, Senthilkumaar P, Kalyanaraman V, Eswari S. Acute toxicity of some agriculture fertilizers to fingerlings of Catla catla. Indian J Sci Technol 2011;4(7):770-2.

16. Capkin E, Kayis S, Boran H, Altinok I. Acute toxicity of some agriculture fertilizers to rainbow trout. Turk J Fish Aquat Sci 2010;10:19-25.

17. Benli AC, Koksal G. The acute toxicity of ammonia on tilapia (Oreochromis niloticus L.) larvae and fingerlings. Turk J Vet Anim Sci 2005;29:339-44.

18. Daud SK, Hasbollah D, Law AT. Effects of un-ionized ammonia on red tilapia (O. mossambicus X O. niloticus Hybrid). Second Int Symp Tilapia Aquac Bangkok, Thail 1988;15:411-3.

19. Bhakta JN. Ammonia toxicity to four freshwater fish species: Catla catla, 
Labeo bata, Cyprinus carpio and Oreochromis mossambica. El J Biol 2006;2(3):39-41

20. Rao RK, Rani AS, Neeraja P. Ambient ammonia stress on detoxification enzymes in brain tissue of fish fingerlings of Cyprinus carpio. IJSR
2014;3(1):491-3

21. Ijaz N, Iqbal Z, Chaudhry JA. Toxicity of ammonia to fingerling grass carp, Ctenopharyngodon idella (Valenciennes). Punjab Univ J Zool 2010;26(1):9-20. 